DOI: https://doi.org/10.31539/leea.v1i2.179

\title{
THE APPLICATION OF FOUR CORNER DEBATE TO TEACH SPEAKING
}

\author{
Nury Kurnia ${ }^{1}$ \\ IKIP Jember, Indonesia \\ nurykurnia@gmail.com ${ }^{1}$ \\ Submit, 12-04-2018 Accepted, 29-05-2018 Publish, 29-05-2018
}

\begin{abstract}
The research aims at knowing and finding whether or not the application of four corner debate is effective to improve students' speaking skill at the eighth grade students of SMP Jamaluddin Ar-Rumi Jatisari Jenggawah Jember in academic year 2016/2017. The population of the study was 78 students with the number of sample 31 students in class VIII B. The research was a pre-experimental research in which only one class which was treated using the technique. The data collection was administered through conducting speaking test and scored students performance. Afterwards the scores were converted to the school passing grade and then calculated in paired t-test. The result showed some data including students' average score in pretest and posttest. The average score in pretest was 67.59 and 76.15 in posttest. It indicated an improvement for 8.65 points. The result of paired t-test calculation was 8.61 and the t-table score was 1.697with 0.05 significance level of score and DF 31 (32-1). The score analysis indicated that the t-test score was higher than the t-table score. Therefore, the null hypothesis (Ho) was rejected and the alternative hypothesis (Ha) was approved which means the application of four corner debate in the classroom is effective to teach English speaking to the eighth grade students of SMP Jamaluddin Ar-Rumi Jatisari Jenggawah Jember in academic year 2016/2017.
\end{abstract}

Keywords: four corner debate, English speaking, teaching speaking

\section{INTRODUCTION}

Producing words orally in a productive skill as in speaking require the connection between brain and speech organ (Rieber, 2014:90). Speaking is one of man's most complicated skills (Levelt, 1989:76). Someone must have sufficient input of information which he received to, then, produce it into spoken words because speaking is delivering ideas or thought through speech organ. Therefore, it is impossible to deliver it if there is no sufficient information or nothing at all. 
The activities with highest priority for interpersonal competence are oral (listening and speaking), which function in processing both input and expression (Saville-Troike, 2006:137). To have a good interpersonal competence in oral communication it is important to master our speaking skill, especially in English language. Speaking is the activity when someone may share the ideas to others orally. In the activity, there are two sides who involve namely a speaker and a hearer (interlocutor). They have to understand each other to communicate well.

Speaking or using the languages also let people to use more than one language. Speaking other languages may cause some difficulties without sufficient knowledge of particular language. Understand the language more familiar to us is easier than understand the new ones. In this case, a foreign language may be more difficult to understand because of significant difference of linguistic features. English as the foreign language in Indonesia confuses the people with variants first and second languages. Because the activity of speaking in English needs special ability, they have to try harder in mastering speaking with some criteria like fluency, pronunciation, vocabulary mastery and grammar. Those criteria are supporting each other in order to have good communication.

In mastering English skills, people also have to master the aspects well. The skills and aspects must be one unity and they cannot be separate each other. If people have a good speaking mastery, they must master the supporting component like pronunciation, enough vocabulary, good grammar and they have to speak in a good order and manner. All of the components are important to have a good mastery in speaking English (Manroe 1997:201).

Some problems tend to occur when an Indonesian tries to learn English. The obstacles of the learners, indeed, become the special concern to English teachers in the country. This is the challenge for all Indonesian English teachers to educate their students to master English as a foreign language. Teachers have to figure out the effective and creative teaching methods that will be adjusted to students learning style.

Speaking problems also happen in different level of education including junior high school students, especially in SMP Jamaluddin Ar-Rumi Jatisari Jenggawah Jember. Observation was ever done know how students speak using a foreign language and what are the problems in triggering them. The result indicated some common students' problems in learning English as a foreign language, such as, lack vocabularies, lack of language experiences, and unsupported environment.

In this study, the writer applied Four Corners Debate to teach the expression of asking and giving opinion. Debate is part of daily life in which people try to 
analyze a topic by comparing and constructing personal experiences, facts, and predictions. But debate is not always confusing because debate can be an interesting activity with some creativity. One of the interesting debate activities is four corners debate. This debate game would attract students to state expression of asking and giving opinion because of the different way of debating. As one of the research conducted previously indicated the effectiveness of using four corners debate to teach speaking to senior high school students. The game was effective since it forced students together in a small group stating their opinion towards something. Expressing different argument is necessary in this debate (Prihatiningtyas, 2013:34). In this activity, students are forced to persuade the students to state the expression to win the game (Shearer, 2001). Therefore, the debate game would be an interesting way to practice and improve students' speaking skill.

\section{LITERATURE REVIEW}

\section{Teaching Speaking}

Saleh (1997:16-21) says that teaching is a profession conducted by using a combination of art, sciences, and skill. It is an art because it relies on the teacher's creative provision of the best possible learning environment and activities for his or her students. It is can be a science because it is a system, an ordered set of ideas and methods used by the teachers in doing their main jobs: planning lesson, implementing the plan in the classroom and evaluating the outcome of the activities. It is also a skill because it demands the ability attained from relevant theories and practice to assist students expertly in learning so that they are able to gain linguistic and communicative competence in the target language.

Moreover, teaching language is not similar to teaching other disciplines, for example in science. In science, students need more projects of experiment and no need to interact each other. But in teaching speaking, teachers have to push students to communicate using the language. Students have to be active to speak each other to practice the skills. They cannot just be quit or sit on the chairs without practicing using their speech organs.

English is a foreign language for Indonesian students. It needs a lot of practice in learning. Teachers also have to teach it passionately creative and patient because they have to stimulate students to learn and practice the language without being boring. Teaching English also require sufficient information and knowledge to support teaching and learning effectively. Both teachers and students have to focus on the skills and aspects in English which are different from their first and second language. 
Good communication is supported by good speaking skills. But most of English as foreign language (EFL) learners face some difficulties toward the skill. Speaking is natural skill which a person begins to develop the first year in life. Speaking is the ability to convey meaning and transfer it to the interlocutors. It is the active use of language to express meaning to therefore it will make sense for other people.

Moreover, Chaney and Burk (1998:13) states that speaking is the process of building and sharing meaning through the use of verbal and non verbal symbol, in a variety of context. Speaking is the crucial part in language learning. In speaking, human must use the symbols correctly to fulfill what they need to say.

Speaking is the complex skill. There are many aspects that must be master, such as, vocabulary, pronunciation, grammar, and comprehension (Richard, 1985: 200). In speaking, learners must attempt to make all of them mastered the elements in harmony to create a good communication. Therefore, teachers have to be more creative and innovative in figuring the latest methods and media to promote students English skills.

\section{Four Corners Debate}

This collaborative strategy requires students to work and think together. It is a perfect involving writing, inquiry, collaboration and reading. Students take a position on a particular topic and move to one of four corner of the room to collaborate with other students with similar views. Each corner puts together an argument to present to the other three corners. Students listen to each other, and have the chance to change opinions and move to another corner if they are persuaded by another corners argument.

Snider and Schenurer (2002:2) define debate is an equitably structured communication event about some topic of interest with opposing advocates alternating before an opportunity is given for decision based on. On the other word, debate will encourage those people involved to deliver the reasonable and organized arguments structurally in order to their decision that is believed. Moreover, all the arguments will not be simply delivered without showing how the connection of those arguments. So, the word "structured communication" will help to know that debate absolutely a series of transmitting point of view inherently and chronologically.

Debate is an excellent activity for language learning because it engages students in a variety of cognitive and linguistic ways. The purpose of this paper is to elaborate upon this point by providing a step-by-step guide that will give teachers everything they need to know for conducting debate in an English class. 
In addition to provide meaningful listening, speaking and writing practice, debate is also highly effective for developing argumentation skills for persuasive speech and writing. Davidson in Ernidawati (2002:3) wrote that "with practice, many students show obvious progress in their ability to express and defend ideas in debate [and] they often quickly recognize the flaws in each other's arguments".

Debate can be fun. This is the interesting statement that a serious debate can be fun with a creative mind of teachers. Teachers can be creative in thinking the debate games and apply it for teaching. One of the debate games is Four Corners Debate. The implementation of this debate game in teaching got a positive reaction from the students.

Four corners debate is one of collaborative strategy which requires the students' activity to work and think together (Hopkins, 2003:89). This activity introduces students to a persuasion. By the end of the lesson, students are able to express their positions, as well as opposing arguments, on a particular issue.

According to Shearer (2001:21), the objectives of the activity, namely, (1) Students will work in groups to clearly verbalize their positions on a specific issue/topic, (2) Students will practice listening skills while other groups present their positions, (3) Students will be able to use convincing arguments to sway others' opinions, and (4) Students will write a 5-paragraph persuasive essay that presents point of view clearly and addresses opposing positions.

Persuasion in this activity means the students of four corners have different position to try to manipulate others. In each corner, students must make sure the other students outside the group of four corners. It is interesting when the students in the four corners groups try to convince the other students that their opinion or argument make them agree. If they agree they have to join one of the groups. If they disagree they free to choose which group to join or no group to join at all.

This activity requires students' movement and cooperation because they have to discuss and cooperate together in giving the opinion. It is a group activity but they have to move and may change the position if they change their mind.

According to Hopkins (2003:98), Four corners debate also can be applied by some extension activities such as, provide time for students to read the paper aloud, the provide times for peer reaction. First, ask students to share only positive comments about their classmates' papers; then provide times for students to share only constructive criticism.

In conclusion, debate is not a complicated activity to be applied as long as teachers are creative to modify them. One of the debate games is four corners debate 
which can be implemented cooperatively by creating the situation that will make students to cooperate and think together.

\section{Invitation}

There are three main points in the expression of invitation such as inviting, accepting and declining invitation (Tim Sigma, 2016:46).

Making invitation

1. Woud you like to...?

2. What about...?

3. Let's go to...

4. I would like to invite you to...

5. I was wondering if you'd like to... Accepting Invitation

1. Yes, thanks.

2. That would be wonderful.

3. Okay/Alright.

4. Thanks for your invitation/I'd be delighted to.

5. Thank you. I'd love to

6. Of course

Refusing Invitation

1. Thanks for asking, but I'm afraid I' busy

2. I can't. I've got a lot of work to do

3. Sorry. I', already tied up

4. I'm awfully/terribly sorry. I have other plans.

5. I'd really like to, but I have an appointment that day.

Some expression above are only several examples which can be used to making invitation of certain events, accepting invitation what we intend to go and declining invitation politely that we do not want to attend to. Some polite expression is required to avoid misunderstanding in using English expression especially for EFL learners.

\section{Previous Research}

In this study, the writer found a thesis which is relevant to the writer's study. The thesis entitled "The Implementation of Debate in Teaching Speaking at Eleventh Year Students of SMA Negeri 2 Rembang in the Academic Year 2011/2012”. This thesis was written by Khoironiyah in 2011. The writer conducted a research to treat students with debate in the classroom. The result of Khoironiyah's thesis was, after 
collecting the data, she concluded that the implementation of debate gave influences in speaking skills of the students and the method can be used as the alternative to teach speaking. The result indicated that the application of debate is effective to teach speaking at eleventh year students of SMA Negeri 2 Rembang in Academic Year 2011/2012.

The writer used a debate game which is expected to be more interesting than just common debate. Fukuda (cited in Krieger, 2005:90) states that in a debate study conducted with Japanese students, found the improvement of students' activity in expressing their opinion after the debate. They have managed their anxiety very well and it presented the improvement from $30.8 \%$ to $56.7 \%$. he said that the debate activity made the students were more familiar and habitually like to express their opinions. This suggests that, although debate is quite challenging, non-native speakers can develop the debating skills which are described in this paper.

Four corners debate was ever been applied by Erlin Prihatiningyas from STKIP PGRI Lubuklinggau to the eleventh grade students of SMA Negeri Purwodadi in 2013. The application of four corners debate was effective to teach speaking and it was proved by the result of paired t-test which present significant score 8.61 with ttable 1.684. the students' scores were also raised from the average score 54.23 to 71.66. It can be conclude that applying four corners debate was a good and effective way to teach speaking asking and giving opinion among the eleventh students of SMAN Purwodadi.

\section{RESEARCH METHOD}

In doing the study the writer applied pre-experimental research design by only treating one experiment class. The experiment class was treated by using four-corners debate to teach speaking skill in SMP Jamaluddin Ar-Rumi. The sample was 31 students in class VIII B out of 78 students at the eighth grade students as the population.

The study was conducted through collecting the data by giving the pretest and posttest to students in collecting students' scores in speaking. The test was an oral test by asking students spoke by having dialogue with a partner about giving, accepting and refusing invitation. After the pretest, there were four meetings of treatment to teach speaking with the topic giving and refusing invitation with different situation.

After collecting the data, they were analyzed through some steps including calculating students' scores, converted the scores to the passing grade and paired ttest. In scoring, the rubric by Harris (cited in Wicaksani, 2013:56) was used. The scoring rubric is as follow. 
Table 1. Harris Scoring Rubric

\begin{tabular}{ll}
\hline \multicolumn{1}{c}{ Speaking Criteria } & \multicolumn{1}{c}{ Max Score } \\
\hline Pronunciation & 20 \\
\hline Grammar & 20 \\
\hline Fluency & 20 \\
\hline Vocabulary & 20 \\
\hline Comprehension & 20 \\
\hline Total score & 100 \\
\hline
\end{tabular}

The scoring was done by two raters namely the writer and the English teacher in the school. Scoring criteria by Harris presents five criteria including pronunciation, grammar, fluency, vocabulary, and comprehension with maximum score 20 for each criteria. Data collection was conducted by recording the students' performance about making invitation, accepting and refusing invitation.

\section{FINDING}

The findings are presented in the section including the results of some calculation in numerical data such as students' mean in the pretest and posttest, and pair $\mathrm{t}$ test. Students' scores in the pres test and post test are presented in the following chart.

Chart 1. Students' Score in the pre test and post test

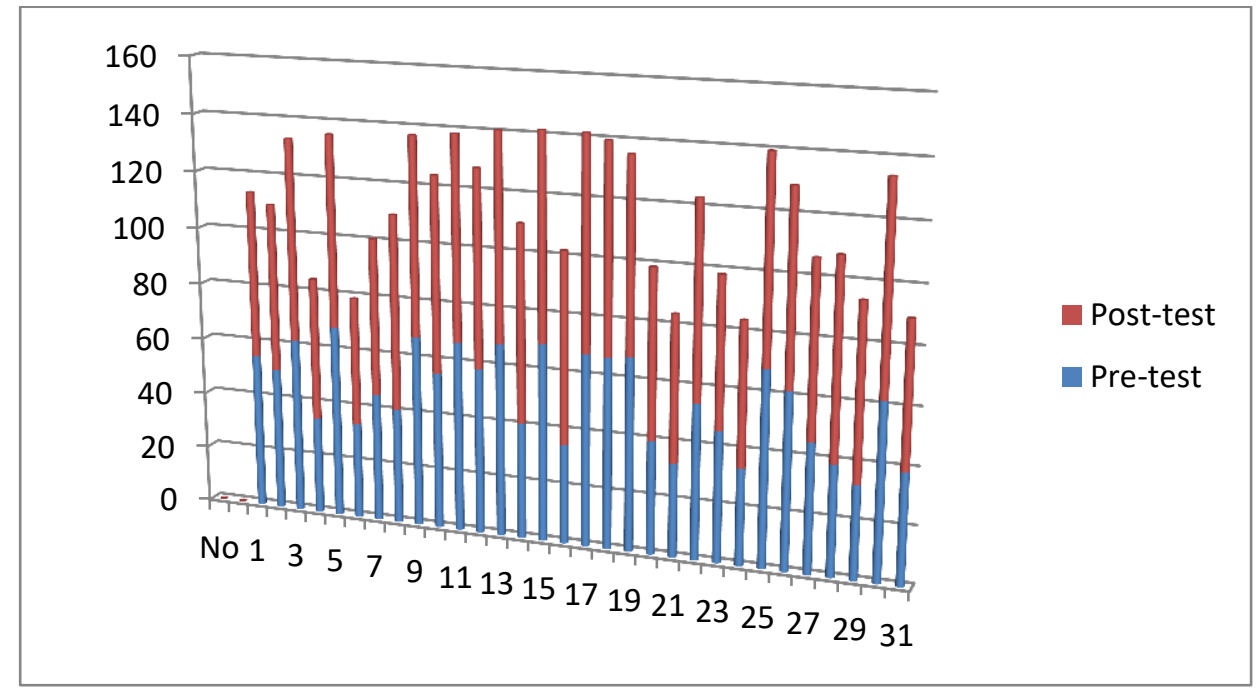


According to the chart, there are significant difference between the scores in the posttest indicated by the red lines and scores in the pre test indicated by blue lines. It means there is an improvement in students' scores of speaking. Furthermore, the scores were converted to the school passing grade and presented in chart 2 as follow.

Chart 2. Students Scores Converted by Passing Grade in the Pretest

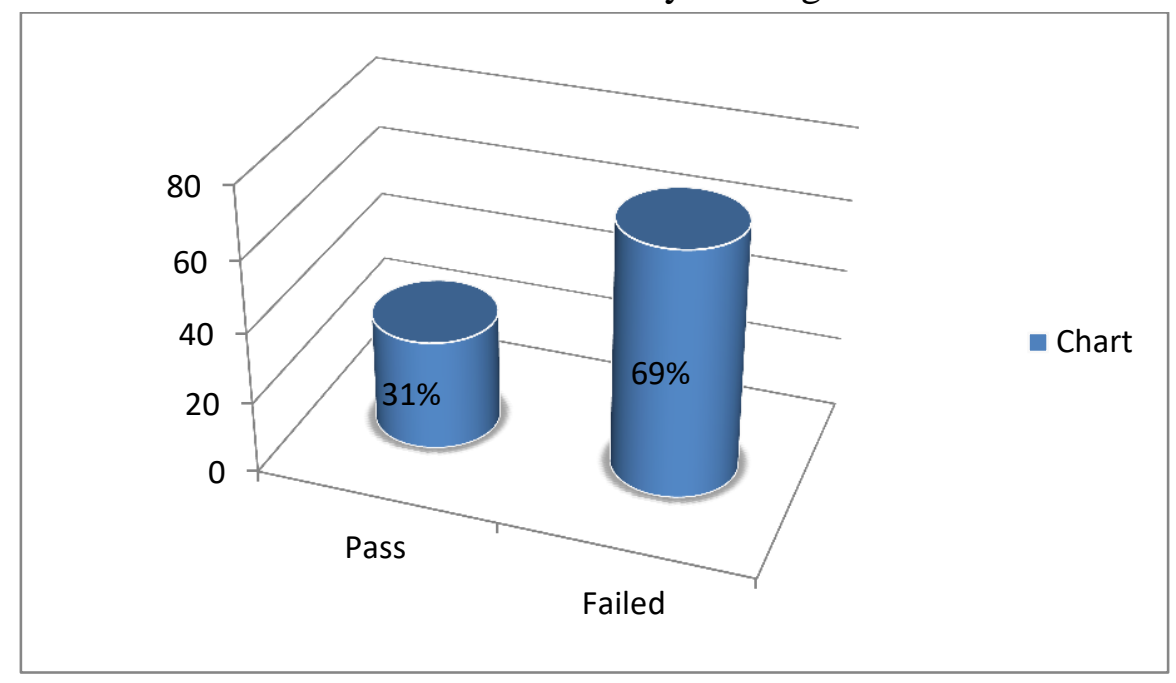

In the chart, it was presented that in the pretest there are many students whore failed when instructed to speak English. It was $69 \%$ of the failure after the scores is converted to the passing grade. Students who were passed through the passing grade was only $31 \%$. The conversion to the posttest scores are presented as follow.

Chart 3. Students Scores Converted by Passing Grade in the post test

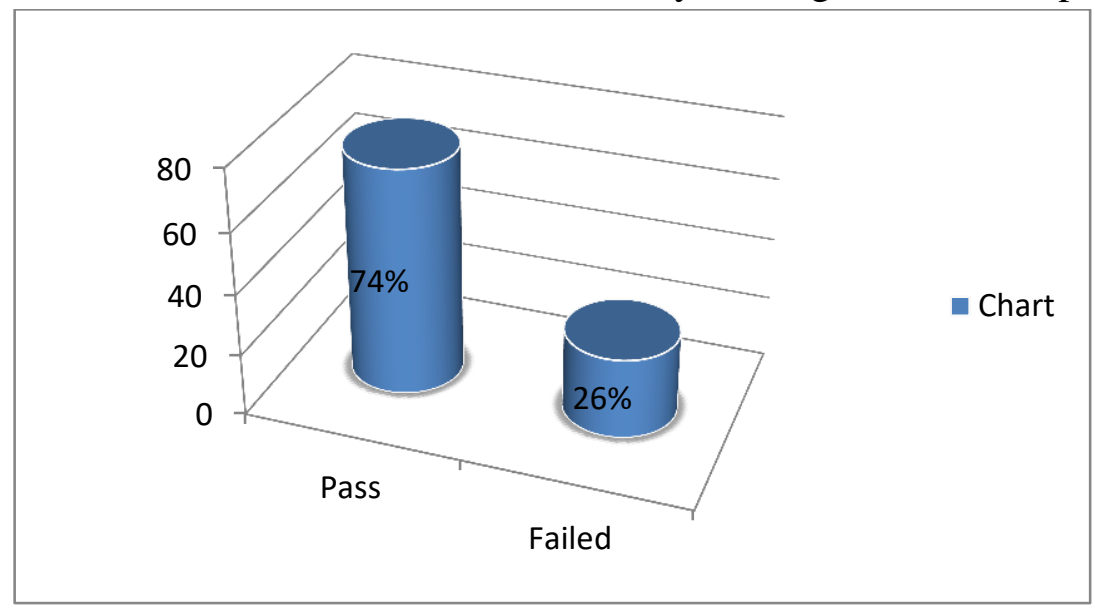


In the chart, it was presented that in the pretest there are many students whore failed when instructed to speak English. It was 26\% of the failure after the scores is converted to the passing grade. Students who were passed through the passing grade were $74 \%$. The improvement was 48 points.

Based on the calculation of normality testing in the pre-test, the table of the list frequency of the observation and expectation of the students' score, the writer found that $\mathrm{X}^{2}$ obtained $=11.262$ with degree of freedom (df) 6 (7-1). Since level is $95 \%$ $(0.05)$, and the $X^{2}$ table $=15.68$. So, it can be concluded that its normal because $\mathrm{X}^{2}$ obtained $=11.262<\mathrm{X}^{2}$ table $=15.68$.

Based on the calculation of normality testing in the pre-test, the table of the list frequency of the observation and expectation of the students' score, the writer found that $\mathrm{X}^{2}$ obtained $=6.83$ with degree of freedom (df) 5 (6-1). Since level is $95 \%$ $(0.05)$, and the $X^{2}$ table $=9.20$. So, it can be concluded that it was normal because $\mathrm{X}^{2}$ obtained $=6.83<\mathrm{X}^{2}$ table $=9.20$.

Paired t test was used to find out the effectiveness of four-corners debate to teach speaking in this pre experimental study. The result of the calculation presented that $t$ score was 7.43 and the critical value was at the significant level 0.05 with $\mathrm{df} 30$ with t table score 1.684 .

Then it can be concluded that the result of t test score 7.34 was much more higher than $\mathrm{t}$ table score 1.684. Thus, the alternative hypothesis was accepted and four-corners debate was effective to teach speaking in SMP Jamaluddin Ar-Rumi in academic year 2016/2017.

\section{DISCUSSION}

As the educators know, teaching English for English as Foreign Language (EFL) students was not easy. They have to be patient and understand what learners need. Teachers' creativity and innovation even is much more required to reach a better goal. In this study, the writer purposed Four Corners Debate to improve students speaking skill so that they can be more active to speak in the class.

No matter how hard, probably, students think about debating, teachers have to push them to speak to make a good habit of speaking. In the study, four corners debate considered to be more interesting in debating because there are some different steps in applying this. The study started by conducting pre-test to get the first data in the school. After doing the pre-test, the treatment was conducted by the application of Four Corners Debate. It was done four times by giving different material to the treatment group (sample). The last data collection was done by conducting the posttest after the fourth treatment. 
In this game, students were allowed to state their opinion and responded asking and giving opinion. They must be active to speak and move to the corner where they agree. Students were active and tried to speak as they can. Some students were good and some had difficulties in doing the debate game. But for all, the game was interesting for students to make them speak.

As conducted by the previous researcher, four corners debate stimulated and forced students to say their opinion. Debating in a group and move based on what they agree and disagree with, made students interested to speak their opinion. The result also showed a significant improvement (Prihatiningyas, 2013:90).

In doing the game, the teacher prepared and set the class into a class with the large space in order to support the game activity. There were four corners which had been prepared to be the place for students to stand in groups. The teacher posted four pieces of papers written by Strongly Agree, Somewhat Agree, Strongly Disagree, Somewhat Disagree. Before playing the game, there were some topics written on the board, namely, invitation to my birthday party (first), invitation to school anniversary (second), invitation to my parents anniversary (third) and invitation to a supermarket opening (fourth).

In the preparation, the students still a little confused look at the corners and the topic. But before the game was played, the teacher explained the rules carefully. They started to move to each corner based on their opinion toward the topic. After there were four students discussed the topic based on the "Strongly Agree, Somewhat Agree, Strongly Disagree, Somewhat Disagree", they started to attract other students to move toward their position. They had to convince that their friends would come to their invitation or refuse the invitation. Some students still lacked of idea to speak. They even repeated the sentence that they friends said before. Some of the students were shy and unconfident to speak the opinion.

After some treatments, the posttest was conducted and finally the result of both pre-test and post-test showed that there was significant difference between students score before the treatment and after the treatment. Before the treatment, the students' average score in speaking test was 51.98 whereas the students' average scores in the post-test was 63. 54. The test was conducted twice by scoring students performance in speaking the expression of giving, accepting and refusing invitation.

Based on the finding, it was known that there was an improvement on students' speaking skill of eleventh grade students of SMP Jamaluddin AR-Rumi. The improvement might be detected by students mean scores and also paired test result. The scoring was done by two raters in avoiding bias scores. Then paired test was done to obtain the result of the effectiveness of the debate. 


\section{CONCLUSION}

There were some limitations of the research found by the writer, such as, students were difficult in speaking directly without preparation, the application was interesting even though it was rather hard to handle because of noisy students, and some students were hard to say their opinion about something.

However, by four times treatment, the result shows a better improvement. By experiencing some challenges, the study by using four-corners debate was effectively successful in teaching speaking. It was proven by statistical procedure which presented the final result in which the $\mathrm{t}$ score was higher than $\mathrm{t}$ table score. Finally, the writer hopes the result of the study might be beneficial for English teachers in improving students' English skills especially speaking skill.

\section{REFERENCES}

Chaney, A.L. \& BurkT.L. (1998). Speaking activities for the English language class room. University of Central Florida.

Ernidawati, T \& Sianturi, O.T. (2002). Improving students' achievement in writing analytical exposition paragraph through debate technique. Unpublished Undergraduate Thesis. Medan: UNIMED.

Hopkins, G. (2003). Four corner debate. Retrieved 6 June 2016 from http://www.educationworld.com/a_lesson/03/lp304-04.shtml

Khoironiyah. (2011). The implementation of debate in teaching speaking at eleventh year students of SMA negeri 2 rembang in the academic year 2011/2012". Undergraduate Thesis. Unpublished. FKIP Unirow Tuban.

Krieger, D. (2005). Teaching debate to ESL students: A six-class unit. The internet TESL journal. 11 (2). Retrieved January 20, 2016 from http://iteslj.org/Techniques/Krieger-Debate.html

Levelt, W.J.M. (1989). Speaking: From intention to articulation. Cambridge: MIT Press

Manroe, V. (1997). Basic English speaking. Surabaya: Greinsinda Press Surabaya

Richards. (1985). Longman Dictionary of Contemporary English. London: Group Limited.

Rieber, R.W. (2014). Language developement and aphasia in children: New essay and a translation. New York: Academic Press.

Prihatiningtyas, E. (2013). Improving speaking skill through four corners debate to the eleventh grade students of SMA Negeri Purwodadi. Unpublished Undergraduate Thesis. Lubuklinggau: STKIP-PGRI Lubuklinggau.

Saleh, Y. (1997). Methodology of TEFL in the Indonesia Context Book 1. Unpublished Manuscript Indalaya: Faculty Of Teacher Training and Education Sriwijaya University. 
Saville-Troike, M. (2006). Introducing second language acquisition. Cambridge: Cambridge University Press.

Shearer, L, M. (2001). Four corners debate: Debates games and activities guide. Retrieved June 16, 2016 from www.sasksdebate.com

Snider, A \& Schenurer, M. (2002). Many sides: Debate across curriculum. New York: The International Debate Education Association.

Tim Sigma. (2016). Top book SMP Kelas VIII. Gasindo: Jakarta.

Wicaksani, W. A. (2013). Using digital discussion through commenting blog to improve students' ability in writing analytical exposition text. English language teaching forum. 2 (1), p 1-12, retrieved June 16, 2016 from https://journal.unnes.ac.id/sju/index.php/elt/article/view/1562 